\title{
IMPACT OF RINSING IN PESTICIDE PACKAGING WASTE MANAGEMENT - ECONOMIC AND ENVIRONMENTAL BENEFITS
}

\author{
UDC: 628.4 .045 \\ Original Scientific Paper \\ Una MARČETA ${ }^{1}$, Bogdana VUJIĆ \\ ${ }^{1}$ University of Novi Sad, Technical faculty “Mihajlo Pupin” Zrenjanin, 23000 Zrenjanin, Đure Đakovića bb, \\ Republic of Serbia \\ E-mail: una.tasovac@tfzr.rs \\ ${ }^{2}$ University of Novi Sad, Technical faculty "Mihajlo Pupin” Zrenjanin, 23000 Zrenjanin, Đure Đakovića bb, \\ Republic of Serbia
}

Paper received: 04.11.2015.; Paper accepted: 30.11.2015.

\begin{abstract}
Pesticides have become dailiness due to inevitable application of these preparations in agricultural activities, with the consequence of generation of large amounts of waste packaging. Impact on the environment and expenses of management of packaging waste can be minimized if the packaging is immediately rinsed after the application of devices and if identified as non-hazardous. Besides, financial losses may be reduced by maximum utilization of the preparation. Considering these two financial aspects this work shows evaluation of quantitative losses of preparations if the triple rising method is not applied. The research was conducted in two phases. Phase I included the examination of the impact of different formulations of the same volume on quantitative and financial losses. Based on the results of the first phase of the research, it was noted that the SC formulation is the most interesting to study because this type of formulation has the highest percentage of residue, as well as the fact that the highest annual consumption is noted percisely in this preparation group. This paper presents the results which indicate the impact of packaging volume of SC formulation (ALVERDE 240 SC, INTERMEZZO and ANTRE PLUS) on percentage of preparation residue in packaging if there was no rinsing. The results have shown that the quantitative loss is inversely proportional to the volume of packaging, while financial losses do not only depend on the percentage of residue but also on price and quantity of utilization of preparations.
\end{abstract}

Keywords: pesticide packaging, hazardous waste management, benefits from rinsing.

\section{INTRODUCTION}

Nowadays, huge amounts of various toxic compounds reach the environment. Many componunds are, when in biosphere, included in equilibrium processes and cycles that occur, and like boomerang, return to man. The global energy and food crisis is the basic characteristic of the last century. Pesticides, among other things in this moment, and probably for a longer period, are daily necessity and concern of man especially in the field of providing the required food quality and quantity. Unlike most polluting substances which reach the environment without any specific goal, pesticides are (although reached from sources that are specific for other pollutants) used to help in a sense that supression of harmful species increases yields in agriculture, fruit growing, viticulture and forestry. However, like all pollutants, pesticides also trigger a series of chain, uncontrolled reactions so their presence in the environment cannot remain unnoticed. The impact of pesticides on the biocenosis is very complex and versatile. The consequences of pesticides effectiveness depend on the nature of a part or the whole system, as well as on physical properties of used products. The level of their negative impact is defined by the importance of the given ecosystem for man. (Marković et al., 1996; Jović et al., 1988)

EPA (Environmental Protection Agency) defines pesticides as any substance or compounds of substances that are used for destruction, suppression and prevention of harmful organisms, (Tomašević, 2010). Pesticides and plant protection products (PPPs) are often considered as synonyms, 
although the term pesticide has wider range of meaning. PPPs involve only products that protect plants and plant products against harmful organisms whereas pesticides include veterinary preparations and sanitary and pest control preparations in humans, (Janjić, 2005; COM, 2002).

Primary sources of pollution caused by pesticides are devices for their direct dispersal, but every environment affected by pesticides becomes primary and secondary pollutant source (agricultural and non-agricultural areas, aquatic ecosystems, etc.). A significant source of secondary pollution of pesticide application represents the used packaging of the products (Stajkovac et al., 2009). The European Association for the Crop Protection ECPA estimates that 34.000 tons of PPPs packaging is placed on the market each year. France, Italy, Spain, Germany, UK, Portugal, Poland and Turkey put the largest amount of packaging on the market. At least $80 \%$ of the PPPs packaging are plastic packaging, mainly HDPE (high density polyethylene) then PET (polyethylene terephthalate), while the rest is paper based and thin film based. Plastic packaging is most commonly used for packaging of liquid products and composites while paper packaging is used for solid formulations. (ECPA, 2007) Given the fact that in Serbia there is no precise data on the generation of packaging waste of this type on annual basis (taking into account the fact that Serbia is predominantly focused on agricultural production as well as that it has about 5.11 million hectares of agricultural land and 4.25 million hectares of arable land (Gulan and Umićević, 2005) where during the chemical treatment several tons of pesticides are being used) it can be assumed that the amounts of waste packaging are not negligible.

Pesticide packaging waste is not commonly classified as hazardous waste. If the packaging waste is classified as hazardous, handling, transportation and disposal must be carried out in accordance with the legal provisions relating to hazardous waste, (Briassoulis et al., 2014). Given that the management of hazardous waste is characterized by high complexity, due to an extremely expressed risks of its release and penetration into environment, by which all human beings and the quality of the environment are jeopardised (Panić, 2010), it is highly important to approach decontamination of packaging immediately after the usage of pesticides. With proper packaging rinsing, it is possible to reduce the concentration of active substances below the limit values for classification of packaging as nonhazardous which are prescribed by European waste catalog, (ECPA, 2007).

The first step towards classification of waste packaging as non-hazardous is adequate rinsing immediately after the application of preparations. There are three basic techniques for waste packaging rinsing from pesticides and these are triple rinsing, rinsing under pressure and integrated rinsing. These standard options for rinsing are developed by international entities like ECPA (European Crop Protection Association), FAO (Food and Agriculture Organisation of the United Nations), WHO (World Health Organization) and CropLife (Briassoulis et al., 2014). All three methods are sufficiently effective in the sense of decontamination and sorting of packaging in the category of non-hazardous waste, if properly used. Triple rinsing is mostly used method because it is very simple and does not require additional equipment. (CropLife, 2004; Briassoulis et al., 2014) It is also very effective because it removes more than $99.99 \%$ of contaminated remains, (CropLife, 2004). Triple rinsing may be applied to all sizes of packaging but is more suitable for smaller bottles, which can be hand-shaken. For larger packaging, rinsing technology is somewhat different, (FAO/WHO, 2008).

Thus, the classification of PPP waste packaging depends on the amount of hazardous substances that remain in the bottle after rinsing, in accordance with EWC by which the lowest limit amount is $0.1 \% \mathrm{w} / \mathrm{w}$ of the total quantity of the preparation in the bottle, and refers to very toxic substances, whereas for toxic substances the lowest limit is $3 \%$. (Briassoulis et al., 2014) Within the EU there are different approaches to classification of rinsed waste packaging, wherein at least a third of countries classifies this packaging as dangerous. In some countries this problem has not yet been considered by the competent institution so it is not possible to obtain the data. Inconsistency in this sense throughout the whole Europe has great present and future consequences for programs of collection and reuse of PPPs packaging. (Huyghebaert et al., 2004)

If the amount of agrochemical composition residue in packaging is small enough for it to be classified as non-hazardous, it offers new possibilities for the valorization as "clean" packaging. In this case, easily controlled and ecological conditions of disposal, recycling appliance and energy 
production are possible. Besides the reducing of disposal costs, it gives possibilities for economical profit and new working places, especially in the case of recycling appliance. (Briassoulis et al., 2014).

Another category of PPPs packaging rinsing relates to problems of environmental protection and human and animal health. With packaging rinsing, the risk of soil and water contamination is minimized. Besides, chances of harmful exposure of users, environment and animals are reduced if rinsing is done immediately after discharging of preparation into sprinkler. Reduced exploitation of natural resources and energy saving are the benefits arising from the use of this waste packaging as recyclable material, or as an alternative fuel in the industry which leads to reduction of waste. (Briassoulis et al., 2014)

The aim of this research is to evaluate financial loss of the Cooperative if there was no proper rinsing through the display of preparation quantity loss.

\section{MATERIAL AND METHODS}

Evaluation of losses caused due to inadequate treatment of waste packaging was done in the agricultural cooperative "Agro Klek" which is located in the municipality of Zrenjanin and deals with livestock and crop production. The dominant implementation includes pesticides of liquid formulations: SC - suspension concentrate, EC emulsified concentrate and SL - soluble concentrate.

The evaluation was carried out for the formulation type SC which takes a dominant position by application rate on an annual basis. Measurements included six samples for each of the three selected mixtures of different volumes $(50 \mathrm{ml}, 250 \mathrm{ml}$ and $1000 \mathrm{ml}$ ) and involved measuring the weight of empty packaging after its discharge into devices used for preparation dispersion and measurement of the same packaging after applied triple rinsing technique according to the guidelines of the WHO guide, (FAO/WHO, 2008). Digital scale "KERN $\mathrm{KB}$ " with technical precision of $0.01 \mathrm{~g}$ was used for measurements.

\section{RESULTS AND DISCUSSION}

The research on the amounts of residual pesticides in waste packaging was carried out in two phases Phase I included measuring of the residual amount of the preparation in non-rinsed pesticide packaging of different formulations (SC suspension concentrate, EC - emulsified concentrate and SL - soluble concentrate) in packaging of the same volume $(1000 \mathrm{ml})$. Based on the measurements it was concluded that the greatest amount of residual preparations was in packaging formulation type SC (Marčeta et al., 2015). Considering that fact, additional research was carried out (Phase II) Residual amount of preparation in non-rinsed SC formulation packaging was also measured. At this stage, the research included three preparations (ALVERDE 240 SC, INTERMEZZO and ANTRE PLUS) of the same formulation - SC, but of different packaging volume $(50 \mathrm{ml}, 250 \mathrm{ml}$ and $1000 \mathrm{ml})$.

Also taking into account the fact that within the agricultural cooperative "Agro Klek" on the level of production year, the most frequently used liquid formulations are: SC formulation (over $31.25 \%$ of the total number of preparations), it was found that significant financial losses could be expected. The basic characteristics of the tested preparations are given in Table 1 and Table 2.

In order to obtain the data on the percentage of preparations residue in packaging if the packaging is not properly rinsed, the measurement of six samples per each was carried out in two cycles: emptied packaging and packaging after triple rinsing. Based on the weight difference, the amount of the residual preparations in the bottle was calculated. Residue percentage, in relation to total weight of the full bottle and financial losses on annual basis if triple rinsing was not applied, were calculated.

The measurement results that show loss within the chosen formulation (SC), but of different types of preparations and packaging volume $(50 \mathrm{ml}, 250$ $\mathrm{ml}, 1000 \mathrm{ml}$ ) are shown in the Figure 1 and Table 3.

The results which show the percentage of residue in the bottle without rinsing within SC formulation have shown that the volume of the packaging has direct impact on the percentage of residue. It is shown that minimal packaging volume of $50 \mathrm{ml}$ of ALVERDE 240 SC preparation has the highest residue level $(11.67 \%)$, followed by $250 \mathrm{ml}$ packaging of INTERMEZZO preparation $(7.87 \%)$ and finally $1000 \mathrm{ml}$ packaging of ANTRE PLUS preparation $(5.05 \%)$. It can be stated that the volume of packaging and the percentage of residue in it are inversely proportional. 
Other researches have shown that after pouring substance into the sprinkler, without rinsing, $2 \%$ of preparation remains in the packaging, (FAO/WHO, 2008). This is generalized data, which represents the average of all pesticides, but if we compare it with the results shown in Figure 1 we notice that the percentages of residue in $\mathrm{SC}$ formulation are significantly higher. A high percentage of residues within SC formulation is the result of physical and chemical features of concentrated suspensions as a solution in which the solid phase is dispersed in liquid, (Janjić, 2005). The density of such formulations is large compared to formulation of the SL and EC and longer-standing of preparations leads to destabilization of solution in the bottle, (Janjić, 2005).

Data on financial loss per one unwashed bottle and per liter of preparation within SC formulation is shown in Table 3.

Table 1: The basic characteristics of the preparations tested

\begin{tabular}{|c|c|c|c|c|}
\hline Preparation & Formulation & Type of pesticide & Packaging & Price per bottle \\
\hline ALVERDE 240 SC & SC & insecticide & $50 \mathrm{ml}$ & 3.94 EUR \\
\hline INTERMEZZO & SC & herbicide & $250 \mathrm{ml}$ & $17.85 \mathrm{EUR}$ \\
\hline ANTRE PLUS & SC & fungicide & $1000 \mathrm{ml}$ & $13.95 \mathrm{EUR}$ \\
\hline
\end{tabular}

Table 2: Active substance (content in litre of preparation), recommended application rate, and annual consumption of products

\begin{tabular}{|c|c|c|c|}
\hline Preparation & $\begin{array}{c}\text { Active substance (content } \\
\text { in liter of preparation) }\end{array}$ & Application rate & $\begin{array}{c}\text { Annual } \\
\text { consumption in } \\
\text { the Cooperative }\end{array}$ \\
\hline ALVERDE $240 \mathrm{SC}$ & $\begin{array}{c}\text { metaflumizone } \\
(240 \mathrm{~g} / \mathrm{l})\end{array}$ & $0.25 \mathrm{l} / \mathrm{ha}$ & 101 \\
\hline INTERMEZZO & $\begin{array}{c}\text { mesotrione } \\
(480 \mathrm{~g} / \mathrm{l})\end{array}$ & $0.25 \mathrm{l} / \mathrm{ha}$ & 301 \\
\hline ANTRE PLUS & $\begin{array}{c}\text { tebuconazole }+ \text { thiophanate-methyl } \\
(167 \mathrm{~g} / \mathrm{l}+133 \mathrm{~g} / \mathrm{g} / \mathrm{l})\end{array}$ & $1.5 \mathrm{l} / \mathrm{ha}$ & 8001 \\
\hline
\end{tabular}

\section{The percentage of residue of the preparation in unwashed bottle within} SC formulation

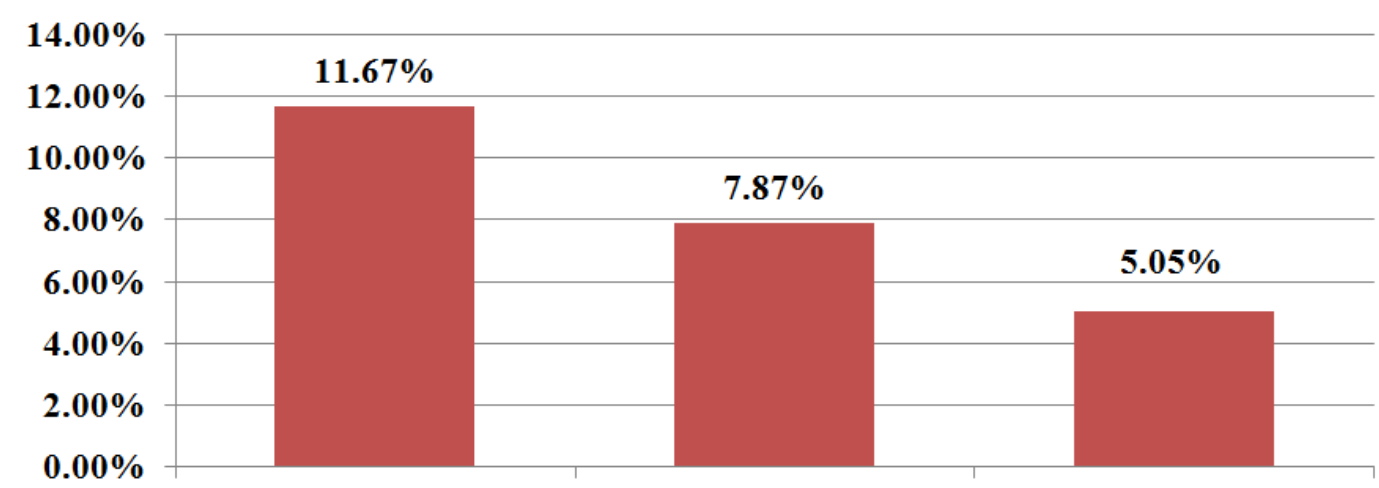

ALVERDE 240 SC, $50 \mathrm{ml}$ INTERMEZZO, $250 \mathrm{ml}$ ANTRE PLUS, $1000 \mathrm{ml}$

Figure 1: The percentage of residue of the preparation in unwashed bottle

Table 3: Financial loss per one unwashed bottle and per liter of preparation within SC formulation

\begin{tabular}{|c|c|c|c|c|}
\hline Preparation & Packaging & $\begin{array}{c}\text { Price per bottle } \\
\text { [EUR] }\end{array}$ & $\begin{array}{c}\text { Financial loss per } \\
\text { unwashed bottle [EUR] }\end{array}$ & $\begin{array}{c}\text { Financial loss per } \\
\text { liter [EUR] }\end{array}$ \\
\hline ALVERDE 240 SC & $50 \mathrm{ml}$ & 3.94 & 0.46 & 9.20 \\
\hline INTERMEZZO & $250 \mathrm{ml}$ & 17.85 & 1.40 & 5.62 \\
\hline ANTRE PLUS & $1000 \mathrm{ml}$ & 13.95 & 0.70 & 0.70 \\
\hline
\end{tabular}

Based on the Table 3 it can be noticed that the financial loss per liter within SC formulation is directly proportional to the percentage of the residue. So, the highest financial loss per liter $(9.20$ EUR) is noticed in ALVERDE 240 SC preparation which have highest percentage of residue, followed 
by INTERMEZZO (5.62 EUR) and ANTRE PLUS (0.70 EUR).

\section{CONCLUSIONS}

The research on the dependence of residual quantities of pesticides in packaging of different volumes was carried out in the framework of agro complex "Agro Klek". The phase I of the research included measurement of residual amounts of different formulations (SC, EC, SL) in packaging of the same volume $(1000 \mathrm{ml})$. The results showed that the highest amount of residual in packaging was noted in formulation type SC. In the same time, in the framework of agro complex during the production year, the most applicable are liquid formulations: SC formulation (over $31.25 \%$ of the total number of preparations), so the analysis (Phase II) of residual amount of SC formulation (ALVERDE 240 SC, INTERMEZZO and ANTRE PLUS), in packaging of different volumes $(50 \mathrm{ml}$, $250 \mathrm{ml}$ and $1000 \mathrm{ml}$ ) was carried out. This paper presents an evaluation of the financial losses due to inadequate treatment of the packaging after using pesticides with SC formulation.

The assessment was conducted by measuring the packaging before and after triple rinsing method. Based on the packaging weight, residual amount of formulations was calculated, which led to conclusion that the packaging volume is inversely proportional to the amount of pesticide residue. These data were used to calculate the total annual financial losses on the level of Cooperative "Agro Klek" that would have occurred as a result of inadequate treatment of the tested packaging waste. The total amount of applications per annum for tested preparations within the SC formulations led to the conclusion that the greatest financial loss is noted within ANTRE PLUS preparation (563.53 EUR), followed by INTERMEZZO preparation (168.57 EUR) then ALVERDE 240 SC preparation (92.05 EUR).

To make the data on financial losses show the financial significance, financial losses must be presented per annum and must be based on the application rate per hectare and the number of acres treated at the level of one production year in the Cooperative, which is a total of 876.62 EUR. Although quantitative losses are inversely proportional to volume of packaging, the financial losses reduced to an annual level are directly proportional to the percentage of residue. This is explained by the price as well as the percentage of preparation utilization. When talking about the financial effects of proper management of pesticide packaging waste, it is necessary to thoroughly examine all procedures and steps that are necessary for adequate management of this waste. This implies that one of the key aspects is that packaging classification should be done immediately after rinsing. If the packaging is identified as hazardous waste, waste management system (handling, transport and disposal) must be carried out in accordance with the legal provisions relating to hazardous waste. It requires special equipment for handling and transportation of this waste, special permission (to ensure compliance) and special facilities for the safe disposal incineration of waste (zero emission). Classification of PPPs waste packaging as dangerous, not only increases costs and makes waste management more complicated but also prevents the possibility of reuse of the packaging materials through recycling.

\section{REFERENCES}

Briassoulis, D., Hiskakis, M., Karasali, H., \& Briassoulis, C. (2014). Design of a European agrochemical plastic packaging waste management scheme - Pilot implementation in Greece. Resources, Conservation and Recycling 87, 72-88.

Commission of the European Communities. (2002). Communication from the Commission to the Council, the European Parliament and the Economic and Social Committee towards a Thematic Strategy on the Sustainable Use of Pesticides (pp.349), Brussles.

CropLife, I. (2004). Container Management: Safe and effective disposal of emptycrop protection product containers, from http://paraquat.com/sites/default/files/Croplife\%20C ontainer\%20Management.pdf

ECPA. (2007 ). Crop Protection Plastic Containers. The case for a nonhazardous waste classification. European Crop Protection Association, from http://www.ecpa.eu/files/gavin/16942_Report\%20on $\% 20$ Classification $\% 20$ of\%20Packagings.pdf

FAO/WHO. (2008). International Code of Conduct on the Distribution and Use of Pesticides (978-92-5106832-8).

http://www.fao.org/fileadmin/templates/agphome/do cuments/Pests_Pesticides/Code/Containers08.pdf

Gulan, B., \& Umićević, B. (2005). The resource of future. Ekonomika poljoprivrede, 4, 421-428.

Huyghebaert, B., Mostade, O., \& Sawa, J. (2004). Management of empty pesticides containers. TEKA Commission of motorization and power industry in agriculture 3, 117-126.

Janjić V. (2005). Fitofarmacija, Beograd.

Jović, C. R., Đarmati, O. Š., \& Jović, N. (1988). Pesticidi, hemija, toksikologija, primena i zaštita 
Marčeta, U., S.Stanisavljev, M.Zakin, N.Petrov, \& D.Bađok. (2015). Cost Reduction as A Result of Proper Pesticide Packaging Waste Management. Communications in Dependability and Quality Management, 18(1).

Marković, A., Šimon, A. Đarmati, Gržetić, I., \& Veselinović, S.D. (1996), Izvori zagađenja posledice i zaštita, In Beograd, (Ed.),Fizičkohemijski osnovi zaštite životne sredine

Panić, M. (2010). Upravljanje opasnim otpadom Planiranje, organizacija funkcionisanje sistema. Beograd: Geografski institut " Jovan Cvijić" SANU.

Stajkovac, J., Amidžić, B., \& Biočanin, J. (2009). Pesticidi i izvori zagađenja $u$ životnoj sredini $i$ značaj remedijacije u sanaciji kontaminacije. Paper presented at the I International conference on Ecological Safety in Post-modern Environment, Banja Luka.

http://apeironsrbija.edu.rs/icama2009/025_Jugoslav $\% 20$ Stajkovac, \%20Amodzic,\%20Biocanin\%20$\% 20$ Pesticidi $\% 20 \% 20 \mathrm{i} \% 20$ izvori\%20zagadenja\%20 u\%20zivotnoj\%20sredini.pdf

Tomašević A. (2010). Prilog proučavanju mehanizma fotodegradacije karbamatnih pesticide, Faculty of Technology and Metallurgy, Belgrade University, Belgrade. 